Herzschr Elektrophys 2018 $29: 1-3$ https://doi.org/10.1007/s00399-018-0556-0 Published online: 25 January 2018

(c) Springer Medizin Verlag GmbH, ein Teil von Springer Nature 2018

CrossMark

\author{
Ursula Ravens ${ }^{1}$ Andreas Goette ${ }^{2,3}$ \\ ${ }^{1}$ Institute for Experimental Cardiovascular Medicine, University Heart Center, Medical Center - University \\ of Freiburg, Faculty of Medicine, University of Freiburg, Freiburg, Germany \\ ${ }^{2}$ Department of Cardiology and Intensive Care Medicine, St. Vincenz-Krankenhaus GmbH, Paderborn, \\ Germany \\ ${ }^{3}$ Working Group Molecular Electrophysiology, University Hospital Magdeburg, Magdeburg, Germany
}

\title{
Advances in cardiac cellular electrophysiology - Relevance for clinical translation
}

The last issues of Herzschrittmachertherapie und Elektrophysiologie focusing on basic mechanisms in cardiac cellular electrophysiology and atrial fibrillation were published more than a decade ago [1,2]. The Editorial Board suggested that reporting the basic science issues of the International Ion Channel Symposium organised by the Working Group on Cellular Electrophysiology (German Cardiac Society) might be a good opportunity for an update [3], but would not fill a whole issue. Therefore, the decision was taken to extend the topic and provide a broader overview of clinically interesting advances in the basic science of the field.

\section{Novel techniques}

Standard clinical diagnostics in cardiology rely on a non-invasive assessment of morphology and function of the heart. The basic principles of new developments in imaging techniques such as cardiac magnetic resonance imaging, computed tomography, optical mapping including optogenetics, photoacoustics, and electron tomography are expertly explained in the first review [4]. Indeed, the authors provide "a new look at the heart" with amazing insights into regional ventricular function, blood flow and tissue motion, especially in a volumetric manner. Evaluation of the images allows quantification of ventricular function for longitudinal follow-up. In the electronmicroscopic world, resolution has been expanded by electron tomography (ET) and by the Nobel prize-winning procedure of cryo-ET [4], which requires the high pressure freezing of samples, but provides an unprecedentedly high image resolution in the range of several angstroms.

Although originally developed to excite single neurons with light by mimicking the nerve-cell depolarizing function of rhodopsin channels in the retina [5], optogenetic approaches are now also employed in the cardiovascular field [6]. Putative cardiac applications include lightinduced pace-making or termination of arrhythmia.

\section{New directions in cardiac cellular electrophysiology}

The familiar body-surface electrocardiogram represents the spatial and temporal vectors of cardiac electrical activity, based on the sum of all action potentials within the various regions of the heart. Each action potential is due to permeability changes of the plasma membrane for the major cations $\mathrm{Na}^{+}, \mathrm{K}^{+}$ and $\mathrm{Ca}^{2+}$ and the anion $\mathrm{Cl}^{-}$. Ion-selective pores within the membrane ("channels") are considered to open and close in a voltage- and time-dependent manner (compare [1]). In recent years it has become increasingly evident that these large membrane-spanning proteins are not only controlled by gene expression and the transcriptional and translational machinery, but that their function is reg- ulated by multiple additional proteins which form macromolecular complexes with ion channels. Heijman and Dobrev provide an update of how these complexes contribute to the intricate finetuning of channel function that is so important for the normal rhythm of the heart [7].

Of the various cardiac ion channels, $\mathrm{K}^{+}$channels appear to constitute the largest (and most heterogeneous) family. During a contraction cycle, the cardiomyocytes are exposed to cyclic mechanical forces that are also transmitted to the lipid bilayer of the plasmalemma. Any distortion of membrane thickness, curvature or membrane in-plane tension can be an adequate gating stimulus for stretch-activated channels. On the other hand, some primarily voltage-sensitive channels such as ATP-inactivated $\mathrm{K}^{+}$channels $\left(\mathrm{K}_{\text {АTP }}\right)$, voltage-dependent, ultra-rapidly activating $\mathrm{K}^{+}$channels $\left(\mathrm{K}_{\mathrm{v}} 1.5\right)$ and different inwardly rectifying $\mathrm{K}^{+}$channels are merely modulated by stretch. Consequently, the next article discusses the role of voltage-dependent $\mathrm{K}^{+}$channels and stretch-activated channels in regulating the cardiac resting membrane potential and the final phase of repolarization, and how their dysfunction in cardiac disease may lead to arrhythmias [8].

The interplaybetween mechanical and electrical phenomena in the heart is also addressed in the context of long QT syndrome [9]. The authors emphasize the necessity for electrical (and mechanical) 
heterogeneity within the heart for physiological excitation and the resulting pumping function. Although both electrical and mechanical heterogeneities are enhanced in long QT syndrome, the increase in mechanical heterogeneity appears to be of greater predictive value for sudden cardiac death than electrical heterogeneity increase.

The last article in this section deals with quantitative in silico modelling of the heart in the highly clinically relevant pathophysiology of myocardial ischemia. It provides an excellent introduction to the basics of multiscale computational modelling and how this technique complements experimental findings to provide a comprehensive understanding of ischemia-related pathophysiology from ion channels to ECG signals [10].

\section{Novel clinical and experimental aspects of atrial fibrillation}

The past two decades have seen enormous scientific interest in elucidating the pathophysiology of atrial fibrillation (AF), its natural history, but also the development of novel treatment strategies and prevention (for review see [11]). Clinically, the duration and frequency of AF episodes are highly variable, and initial episodes of AF may even pass undetected for lack of subjective symptoms. Because of the high association of AF with stroke and cardiovascular morbidity, expert consortium groups have emphasized the need for reliable markers and screening methods for AF [12]. Here, Zink et al. discuss the opportunities and challenges of current efforts to provide large-scale AF screening for the stroke prevention [13]. More research is required before clear recommendations can be made as to which patients should be screened and what the therapeutic consequences should be in case of $\mathrm{AF}$ detection.

The characteristic progression of $\mathrm{AF}$ from paroxysmal episodes to permanent arrhythmia is associated with electrical and structural remodelling processes [14]. Although cellular $\mathrm{Ca}^{2+}$ overload is accepted to contribute to some of the electrophysiological alterations [15], a more comprehensive view has been given recently, where the major players, i.e. oxidative stress, inflammation and fibrosis, as well as cardiomyocytefibroblast interaction and microRNAs have been integrated [16]. Here, the complex functions of fibroblasts and their indirect (via secreted factors) and direct communication with cardiomyocytes (via gap junctions) are outlined in the context of fibrosis, effects on conduction and contribution to electrophysiological remodelling [17].

With the advent of modern DNA sequencing techniques, the exploration of the "transcriptome" of individual AF patients has become feasible and affordable. Likewise, "proteomics" allow detection of all relevant proteins including their posttranscriptional alterations in the course of the arrhythmia. Therefore, the present collection of reviews on novel techniques also contains a compilation of recent literature dealing with changes in expression profiles during AF-induced remodelling [18]. These technological advances, in particular RNA-Seq, and the application of integrative approaches are expected to provide progress in understanding AFrelated alterations.

The last review of this series addresses the problem of thrombogenesis in AF as a major contributor to the high risk of stroke in this disease [19]. The authors recapitulate our current understanding of the coagulation cascade and explain the modern concept of "prothrombotic endocardial remodelling". Based on findings in animal models of AF and in patients, they provide evidence-based recommendations for first-line antithrombotic treatment in AF patients. Importantly, the concept of "atrial cardiomyopathy" is introduced and explained with regard to thrombogenesis [20].

Taken together, the guest editors of this issue of Herzschrittmachertherapie and Elektrophysiologie are convinced that the general reader of the journal will find the information provided not only useful but also an enjoyable reading experience.

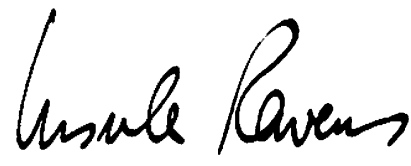

Ursula Ravens

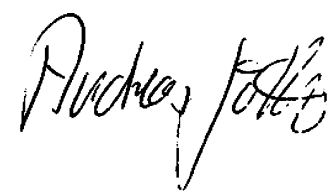

Andreas Goette

\section{Corresponding address}

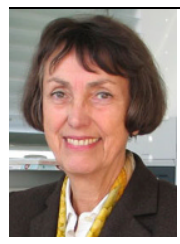

Prof. Dr. med. Dr. h.c. U. Ravens Institute for Experimental Cardiovascular Medicine, University Heart Center, Medical Center - University of Freiburg, Faculty of Medicine, University of Freiburg Elsässer Straße 2Q, 79110 Freiburg, Germany ursula.ravens@uniklinikfreiburg.de

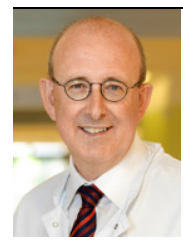

Prof. Dr. med. A. Goette Department of Cardiology and Intensive Care Medicine, St. Vincenz-Krankenhaus $\mathrm{GmbH}$

Am Busdorf 2, 33098 Paderborn, Germany andreas.goette@vincenz.de

Conflict of interest. U. Ravens and A. Goette declare that they have no competing interests.

\section{References}

1. Ravens U (2003) Vom Forschherzen zum lonenkanal. Herzschrittmacherther Elektrophysiol 14:47-49. https://doi.org/10.1007/s00399-0030381-x

2. Ravens U,DobrevD,GoetteA(2006) Newaspects of atrial fibrillation therapy. Herzschrittmacherther Elektrophysiol 17:61-63. https://doi.org/10.1007/ s00399-006-0511-3

3. Voigt NM, Mason F, Thomas D (2018) Report on Ion Channel Symposium organised by the German Cardiac Society Working Group on Cellular Electrophysiology (AG 18). Herzschrittmacherther Elektrophysiol. https://doi.org/10.1007/s00399017-0549-4

4. Johnston CMK, Krafft AJ, Russe MF, Rog-Zielinska EA (2018) A new look at the heart-novel imaging techniques. Herzschrittmacherther Elektrophysiol. https://doi.org/10.1007/s00399017-0546-7

5. Zhang F, Gradinaru V, Adamantidis AR, Durand R, Airan RD, de Lecea L, Deisseroth K (2010) Optoge- 
netic interrogation of neural circuits: technology for probing mammalian brain structures. Nat Protoc 5:439-456. https://doi.org/10.1038/nprot. 2009.226

6. Schneider-Warme F (2018) The power of optogenetics : Potential in cardiac experimental and clinical electrophysiology. Herzschrittmacherther Elektrophysiol. https://doi.org/10.1007/s00399 017-0545-8

7. Heijman J, Dobrev D (2017) lon channels as part of macromolecular multiprotein complexes : Clinical significance. Herzschrittmacherther Elektrophysiol. https://doi.org/10.1007/s00399017-0542-y

8. Schmidt CP, Peyronnet R (2018) Voltage-gated and stretch-activated potassium channels in the human heart: pathophysiological and clinical significance. Herzschrittmacherther Elektrophysiol. https://doi.org/10.1007/s00399017-0541-z

9. Dressler FF, Brado J, Odening KE (2017) Electromechanical heterogeneity in the heart: A key to long QT syndrome? Herzschrittmacherther Elektrophysiol. https://doi.org/10.1007/s00399017-0544-9

10. Loewe A, Wulfers EM, Seemann G (2018) Cardiac ischemia-insights from computational models. Herzschrittmacherther Elektrophysiol. https://doi. org/10.1007/s00399-017-0539-6

11. Kirchhof $P$, Benussi $S$, Kotecha $D$, Ahlsson $A$, Atar D, Casadei B, Castella M, Diener HC, Heidbuchel $\mathrm{H}$, Hendriks J, Hindricks G, Manolis AS, Oldgren J, Popescu BA, Schotten U, Van Putte B, Vardas P, Agewall S, Camm J, Baron Esquivias G, Budts W, Carerj S, Casselman F, Coca A, De Caterina R, Deftereos S, Dobrev D, Ferro JM, Filippatos G, Fitzsimons D, Gorenek B, Guenoun M, Hohnloser SH, Kolh P, Lip GY, Manolis A, McMurray J, Ponikowski P, Rosenhek R, Ruschitzka F, Savelieva I, Sharma S, Suwalski P, Tamargo JL, Taylor CJ, Van Gelder IC, Voors AA, Windecker S, Zamorano JL, Zeppenfeld K (2016) 2016 ESC Guidelines for the management of atria fibrillation developed in collaboration with EACTS Europace 18:1609-1678. https://doi.org/10.1093/ europace/euw295

12. Kirchhof $P$, Breithardt $G$, Bax J, Benninger $G$, Blomstrom-Lundqvist $C$, Boriani $G$, Brandes $A$, Brown H, Brueckmann M, Calkins $H$, Calvert $M$, Christoffels V, Crijns H, Dobrev D, Ellinor P, Fabritz L, Fetsch T, Freedman SB, Gerth A, Goette A, Guasch E, Hack G, Haegeli L, Hatem S, Haeusler KG, Heidbuchel H, Heinrich-Nols J, Hidden-Lucet $F$, Hindricks G, Juul-Moller S, KaabS, Kappenberger L, KespohI S, Kotecha D, Lane DA, Leute A, Lewalter T, Meyer R, Mont L, Munzel F, Nabauer M, Nielsen JC, Oeff M, Oldgren J, Oto A, Piccini JP, Pilmeyer A, Potpara T, Ravens U, Reinecke H, Rostock T, Rustige J, Savelieva I, Schnabel R, Schotten U, Schwichtenberg L, Sinner MF, Steinbeck G, Stoll M, Tavazzi L, Themistoclakis S, Tse HF, Van Gelder IC, Vardas PE, Varpula T, Vincent A, Werring D, Willems S, Ziegler A, Lip GY, Camm AJ (2016) A roadmap to improve the quality of atrial fibrillation management: proceedings from the fifth Atria Fibrillation Network/European Heart Rhythm Association consensus conference. Europace 18:37-50. https://doi.org/10.1093/europace/ euv304

13. Zink MDM, Marx N, Crijns HJGM, Schotten U (2018) Opportunities and challenges of large scale screening for atrial fibrillation. Herzschrittmacherther Elektrophysiol. https://doi.org/10.1007/s00399017-0550-y
14. Wijffels MC, Kirchhof CJ, Dorland R, Allessie MA (1995) Atrial fibrillation begets atrial fibrillation. A study in awake chronically instrumented goats. Circulation 92:1954-1968

15. Heijman J, Voigt N, Nattel S, Dobrev D (2014) Cellular and molecular electrophysiology of atrial fibrillation initiation, maintenance, and progression. Circ Res 114:1483-1499. https://doi. org/10.1161/CIRCRESAHA.114.302226

16. Jalife J, Kaur K (2015) Atrial remodeling, fibrosis, and atrial fibrillation. Trends Cardiovasc Med 25:475-484. https://doi.org/10.1016/j.tcm.2014. 12.015

17. Klesen AJ, JakobD, Emig R, Kohl P, Ravens U, Peyronnet $P$ (2018) Cardiac fibroblasts-new players in (atrial) electrophysiology? Herzschrittmacherther Elektrophysiol 21:217-221

18. Sühling MW, Wolke C, Scharf C, Lendeckel U (2018) Proteomics and transcriptomics in atrial fibrillation. Herzschrittmacherther Elektrophysiol. https://doi.org/10.1007/s00399-017-0551-x

19. Bukowska A, Hammwohner M, Corradi D, Mahardhika W, Goette A (2017) Atrial thrombogenesis in atrial fibrillation. Results from atrial fibrillation models and AF-patients. Herzschrittmacherther Elektrophysiol. https://doi.org/10.1007/s00399017-0543-x

20. Goette A, Kalman JM, Aguinaga L, Akar J, Cabrera JA, Chen SA, Chugh SS, Corradi D, D'Avila A, Dobrev D, Fenelon G, Gonzalez M Hatem SN, Helm R, Hindricks G, Ho SY, Hoit B, Jalife J, Kim YH, Lip GY, Ma CS, Marcus GM, Murray K, Nogami A, Sanders P, Uribe W, Van Wagoner DR, Nattel S (2016) EHRA/HRS/ APHRS/SOLAECE expert consensus on atrial cardiomyopathies: definition, characterization, and clinical implication. Europace 18:1455-1490. https://doi.org/10.1093/europace/euw161 